\title{
THE EFFECT OF CHRONIC IRON LOSSES ON LIVER REGENERATION IN MALE AND FEMALE RATS
}

\author{
Helena Zivna ${ }^{\mathrm{a}}$, Pavel Zivny*b, Doris Vokurkova ${ }^{\mathrm{c}}$, Klara Svejkovska ${ }^{\mathrm{a}}$, Vladimir Palicka ${ }^{\mathrm{b}}$
}

\author{
${ }^{a}$ Radioisotope Laboratories and Vivarium, Medical Faculty, Charles University, Hradec Kralove, Czech Republic \\ ${ }^{b}$ Institute of Clinical Biochemistry and Diagnostics, Medical Faculty, Charles University and University Hospital, Hradec \\ Kralove \\ c Institute of Clinical Immunology, Medical Faculty, Charles University and University Hospital, Hradec Kralove \\ E-mail: zivny@lfhk.cuni.cz
}

Received: November 19, 2009; Accepted: April 1, 2010

Key words: Iron/Respiratory burst/Prohepcidin/Liver regeneration

\begin{abstract}
Background. We studied the effect of iron deficiency on liver regeneration and innate immunity - respiratory burst of PMN.

Methods. Wistar rats, males (M) and females (F) had sham withdrawals or males (M-w) and females (F-w) had nine blood withdrawals every week. All rats were sacrificed in $10^{\text {th }}$ week after $67 \%$ hepatectomy $(\mathrm{PH})$ after ${ }^{3} \mathrm{H}$-thymidin application. We determined erythrocyte and leukocyte count, respiratory burst (RB), serum prohepcidin, estradiol, iron, iron binding capacity (TIBC) and liver iron stores.

Results. Liver DNA synthesis in M-w and F-w increased versus M and F ( $p=0.05)$. Serum prohepcidin after PH decreased in $\mathrm{M}, \mathrm{F}(\mathrm{p}=0.001)$ and $\mathrm{F}-\mathrm{w}(\mathrm{p}=0.05)$, but not in $\mathrm{M}-\mathrm{w}$. Blood withdrawals increased spontaneous $\mathrm{RB}(\mathrm{p}<0.05)$, stimulated RB at females $(p<0.01)$. Stimulated RB was lower in M-w then in $M(p<0.01)$. Serum iron was lower in males than in females, but higher in rats with withdrawals than in rats without withdrawals. TIBC decreased after PH in M, F, F-w groups $(\mathrm{p}<0.001)$, less at $\mathrm{M}-\mathrm{w}(\mathrm{p}<0.05)$. Liver iron stores decreased in $\mathrm{M}$, less in F.

Conclusions. Both genders with blood withdrawals had early beginning of liver regeneration after PH. The preconditioning (withdrawals) leads to increase in iron turnover and stores following best reactivity of PMN, rapid decrease in serum prohepcidin, and early initiation of liver regeneration, mainly in females. We assume, the females have higher iron turnover, liver iron stores more easily mobilized for blood losses, because next gravidity physiologically begin immediately after birth. Simply transfer of experimental results to human medicine is difficult.
\end{abstract}

\section{INTRODUCTION}

The importance of the amount of iron in food and its metabolic turnover in organism has not been satisfactorily solved yet, especially under conditions of the repeated blood withdrawals in blood donors. The relationship between the iron and nonspecific immunity processes is the very important aspect for such pathologic processes, which are linked to iron overloading or insufficiency. Based on clinical and subjective data from blood donors it seems that repeated blood donation might improve general organism health condition, especially reduction of current infectious diseases.

\footnotetext{
ABBREVIATIONS

F - Female rats without blood withdrawals

F-w - Female rats with blood withdrawals

M - Male rats without blood withdrawals

M-w - Male rats with blood withdrawals

PH - Partial hepatectomy

PMN - Polymorphonucleares

RB - Respiratory burst

TIBC - Iron binding capacity
}

Iron absorption and its stores are complex and precise regulated processes, where is participated important protein - prohepcidin - hepcidin. The hepcidin correlate with serum ferritin concentration ${ }^{1}$, inhibits iron absorption in enterocyte $^{2}$, in placenta ${ }^{3}$, and release from macrophages ${ }^{4}$, decreasing the delivery of iron to maturing erythrocytes. Hepcidin expression is inhibited during stimulated erythropoiesis even in situations of elevated iron stores ${ }^{1}$. The liver, primary biosynthetic reservoir of prohepcidin and iron storage organ, plays a key role in the hepcidin response to systemic infection ${ }^{5}$. Prohepcidin - hepcidin, a substrate of macrophagic membrane-associated furin ${ }^{6}$, could be expressed by inflammatory cells in situ and influenced production of IL- 6 and IL- 1 cytokines $^{4}$. The serum furin proteases were demonstrated to be the principle enzyme involved in pro-hepcidin maturation ${ }^{7}$ and in the innate immune response of macrophages too ${ }^{8}$.

Iron is one of the most powerful initiators of lipoperoxidation ${ }^{9}$. The generation of reactive oxygen species (ROS) in the respiratory burst is mediated by the multicomponent enzyme NADPH oxidase ${ }^{10}$. The importance of estrogens for iron metabolism and lipoperoxidation was approved, because the estrogen inhibits oxidative processes in blood ${ }^{11}$. 
The aim of our experiment was to study the effect of repeated blood losses on the iron metabolism, innate immunity and surgical stress adaptation. We performed partial hepatectomy in rats at the end of our experiment to induce surgical stress and to impair main iron store organ. The initiation of liver regeneration presumes regular immune reactivity and health conditions too.

\section{MATERIALS AND METHODS}

Diet preparation. Diet was mix $60 \mathrm{~kg}$ of commercial powdery diet ST-1 (VELAS a.s., Lysa nad Labem, $\mathrm{CZ}$ ) and $20 \mathrm{~kg}$ of defined standard laboratory diet (modified according to specifications in www.testdiet. com), from casein (PML a.s., Novy Bydzov, CZ), cornstarch (Skrobarny Pelhrimov, CZ), cellulose (Phrikolat, Chemishe Erzeugnisse GmbH, Germany), choline chloride, L-cystein, L-arginine and sucrose (Fisher Scientific, Ltd., Pardubice, CZ), corn oil (CANO CZ Ltd, Hermanuv Mestec, Czech Republic), DL-mehionine (Sigma-Aldrich Ltd., Prague, Czech Republic), mixture of vitamins and minerals. The diet was fabricated into granules, which were dried in $60{ }^{\circ} \mathrm{C}$ in food dryer. This diet contains $27 \mathrm{mg}$ of elemental iron per $1 \mathrm{~kg}$.

Animals. The special institutional committee approved the experiment protocol. All blood withdrawals and operations were performed in total ether anesthesia. Adult albino Wistar rats (Konarovice, Czech Republic) were placed in plastic cages according to standard conditions (temperature of $22 \pm 2{ }^{\circ} \mathrm{C}, 12$ hours light/dark, air humidity $30-70 \%)$. The rats were randomly divided into 4 groups 6 rats each with initial body weight (BW): males $315 \pm 7 \mathrm{~g}$, females $211 \pm 3 \mathrm{~g}$. They were fed for 10 weeks with prepared diet ad libitum and they drank ad libitum tap water, where iron had been cleared out by straining the iron through filter (BRITA, Germany). We use the repeated blood withdrawals $(0.5 \mathrm{ml} / 100 \mathrm{~g}$ of BW) from retroorbital plexus.

1. group: males (M), sham manipulation every week, one blood withdrawal in the $9^{\text {th }}$ week.

2. group: females (F), sham manipulation every week, one blood withdrawal in the $9^{\text {th }}$ week.

3. group: males (M-w), blood withdrawal every week, i.e. 9 times total.

4. group: females (F-w), blood withdrawal every week, i.e. 9 times total.

The $67 \%$ hepatectomy $(\mathrm{PH})$ was performed at all rats in the $10^{\text {th }}$ week of experiment. The ${ }^{3} \mathrm{H}$-thymidin $(740$ kBq/100 g of BW, Lacomed Ltd., Rez u Prahy, Czech Republic) was applied i.v. $17 \mathrm{~h}$ after PH. Rats were sacrificed $18 \mathrm{~h}$ after $\mathrm{PH}$ by exsanguination from abdominal aorta. The serum and removed organs were frozen $-80{ }^{\circ} \mathrm{C}$ till analyse.

We analyzed serum iron concentration $(\mu \mathrm{mol} / 1)$, its total iron binding capacity (TIBC) and prohepcidin concentration (pmol/1, Hepcidin pro-hormone EIA-4015, DRG, Germany) and 17ß-estradiol (pmol/1, competitive immunoassay on Immulite analyser).

Samples of liver for determination of iron content were dried, weighed and digested by microwave digestion using nitric acid and hydrogen peroxide (Milestone MLS 1200 MEGA, Italy). The iron concentration ( $\mu \mathrm{g} / \mathrm{g}$ dry tissue) was determined using graphite furnace atomic absorption spectrometry (Unicam, Solaar 959, UK).

Liver DNA synthesis was determined by methyl ${ }^{3}$ H-thymidine ${ }^{12}$ on Beckman Coulter LS 6000 LL (Beckman Coulter, Fullerton, CA, USA). The liver DNA content was determined with diphenylamine reagent ${ }^{13}$.

The blood count was set in fresh heparinized blood by Abbott CELL-DYN 3200 SL (Abbott, IL, USA) and respiratory burst of polymorphonucleares - PMN (oxygen intermediates production with dihydrorhodamine 123 (DHR, Sigma, Prague, Czech Republic) and stimulation with phorbol myristate acetate (PMA, Sigma, Prague, Czech Republic) were performed on an Cytomics FC500 flow cytometer $\mathbf{( 4 8 8}$ nm, Beckman Coulter, Fullerton, CA, USA). Positivity (\%) was recorded either fluorescence signals (575 $\mathrm{nm}$ ). Data were analyzed using CXP Analysis software ${ }^{14}$.

Liver tissue for histopathological examination was obtained from one standard site (processus anterior dexter et processus caudatus lobi caudati) fixed in $10 \%$ buffered formalin. The $3 \mu \mathrm{m}$ paraffin sections were stained with hematoxylin - eosin and for iron by potassium ferrocyanide (PENTA, Hradec Kralove, Czech Republic). The liver iron content was evaluated according to $0-1-2-3$ arbitrary scale.

Statistical analyses were performed by software "SigmaStat 3.1" Jandel Scientific, San Rafael, CA, USA. One sign represents statistical significance $p<0.05$, two signs represent $p<0.01$ and three signs represent $p<0.001$. The comparison of two values signalizes identical symbols. Blood count is expressed as mean \pm SEM, prohepcidin and respiratory burst of PMN are expressed as median (25. and 75. percentile).

\section{RESULTS}

Females had higher liver iron concentration then males. The iron fall in liver was greater in group F-w. The weights of liver after $\mathrm{PH}$ not differentiated in groups with withdrawals from the ones without withdrawals. Female liver weight is lower as their body weight. Rats with withdrawals (especially females) had higher liver DNA synthesis in comparison with the groups without withdrawals.

The rats with blood withdrawals had higher values of iron content in erythrocytes in comparison with the ones without blood withdrawals. Further, concentration of hemoglobin did not decrease at rats with blood withdrawals after PH so significantly like in groups without blood withdrawals. All groups had lower leukocyte count in peripheral blood after $\mathrm{PH}$ in comparison with the ones before PH (data not presented). The rats with blood withdrawals had higher absolute numbers of PMN after $\mathrm{PH}$ in comparison with the ones without blood withdrawals. The repeated withdrawals lead to increase of serum $17 \beta$-estradiol, which even more increase after $\mathrm{PH}$ in all rats, mainly in females. 
Table 1. Liver iron score, total liver iron content, liver weight after PH and specific activity of liver DNA.

\begin{tabular}{|c|c|c|c|c|c|c|}
\hline & \multicolumn{2}{|c|}{$\begin{array}{c}\text { Liver iron score } \\
(0-3)\end{array}$} & \multicolumn{2}{c|}{$\begin{array}{c}\text { Total liver iron content } \\
\text { (ug/g dry liver })\end{array}$} & $\begin{array}{c}\text { Liver weight } \\
(\mathrm{g})\end{array}$ & $\begin{array}{c}\text { s.a. DNA } \\
(\mathrm{kBq} / \mathrm{mg} \text { DNA) }\end{array}$ \\
\hline & $\begin{array}{c}\text { Before } \\
\text { PH }\end{array}$ & $\begin{array}{c}\text { After } \\
\text { PH }\end{array}$ & $\begin{array}{c}\text { Before } \\
\text { PH }\end{array}$ & $\begin{array}{c}\text { After } \\
\text { PH }\end{array}$ & $\begin{array}{c}\text { After } \\
\text { PH }\end{array}$ & $\begin{array}{c}\text { After } \\
\text { PH }\end{array}$ \\
\hline M & 0.4 & 0 & $788 \pm 161$ & $596 \pm 162$ & $5.7 \pm 0.4$ & $1.2 \pm 0.5$ \\
\hline F & 2 & 1 & $1576 \pm 154$ & $1370 \pm 159$ & $3.6 \pm 0.1$ & $\begin{array}{c}0.5 \pm 0.2 \\
*++ \\
++3\end{array}$ \\
\hline M-w & 0 & 0 & $551 \pm 120$ & $538 \pm 123$ & $5.0 \pm 0.6$ & $\begin{array}{c}1.5 \pm 0.3 \\
++\end{array}$ \\
\hline F-w & 1 & 0 & $943 \pm 89$ & $813 \pm 104$ & $3.8 \pm 0.2$ & $\begin{array}{c}1.9 \pm 0.5 \\
*\end{array}$ \\
\hline
\end{tabular}

Results of liver iron score, total liver iron content, liver weight after PH and specific activity of liver DNA in rats before PH and 18 hour after partial hepatectomy. M resp. F - male resp. female sham manipulated, M-w resp. F-w male resp. female blood withdrawal every week. The comparison of two values signalizes identical symbols. One sign represents statistical significance $\mathrm{p}<0.05$, two signs represent $\mathrm{p}<0.01$.

Table 2. Basic hematological values and serum 17ß-estradiol.

\begin{tabular}{|c|c|c|c|c|c|c|c|c|}
\hline & \multicolumn{2}{|c|}{ Hemoglobin (g/l) } & \multicolumn{2}{|c|}{$\mathrm{MCH}(\mathrm{pg})$} & \multicolumn{2}{|c|}{$\begin{array}{l}\text { Absolute number } \\
\text { of PMN (x 109/1) }\end{array}$} & \multicolumn{2}{|c|}{$\begin{array}{c}17-\beta \text { estradiol } \\
(\mathrm{pmol} / 1)\end{array}$} \\
\hline & Before PH & Before PH & Before PH & After PH & Before PH & $\begin{array}{c}\text { After } \\
\text { PH }\end{array}$ & $\begin{array}{c}\text { Before } \\
\mathrm{PH}\end{array}$ & $\begin{array}{c}\text { After } \\
\text { PH }\end{array}$ \\
\hline M & $\begin{array}{c}159 \pm 2 \\
\cdots\end{array}$ & $\begin{array}{c}144 \pm 3 \\
\cdots\end{array}$ & $\begin{array}{c}17.9 \pm 0.4 \\
++\end{array}$ & $\begin{array}{c}17.5 \pm 0.4 \\
\# \#\end{array}$ & $1.1 \pm 0.4$ & $\begin{array}{c}1.2 \pm 0.6 \\
* *\end{array}$ & $<74$ & $86 \pm 4$ \\
\hline $\mathrm{F}$ & $153 \pm 3$ & $145 \pm 4$ & $\begin{array}{c}18.7 \pm 0.4 \\
\mathrm{x}\end{array}$ & $\begin{array}{c}18.3 \pm 0.5 \\
\&\end{array}$ & $\begin{array}{c}1.4 \pm 0.3 \\
+\end{array}$ & $\begin{array}{c}0.7 \pm 0.4 \\
* * *\end{array}$ & $\begin{array}{c}143 \pm 13 \\
\mathrm{xx}\end{array}$ & $196 \pm 26$ \\
\hline M-w & $153 \pm 3$ & $161 \pm 7$ & $\begin{array}{c}19.4 \pm 0.2 \\
++\end{array}$ & $\begin{array}{c}19.3 \pm 0.3 \\
\# \#\end{array}$ & $0.8 \pm 0.2$ & $\begin{array}{c}3.9 \pm 0.6 \\
* *\end{array}$ & $<74$ & $102 \pm 16$ \\
\hline F-w & $155 \pm 1$ & $155 \pm 8$ & $\begin{array}{c}19.8 \pm 0.4 \\
x\end{array}$ & $\begin{array}{c}19.4 \pm 0.5 \\
\&\end{array}$ & $\begin{array}{c}0.5 \pm 0.2 \\
+\end{array}$ & $\begin{array}{c}3.2 \pm 0.4 \\
* * *\end{array}$ & $\begin{array}{c}317 \pm 33 \\
x x \\
(p=0.014)\end{array}$ & $128 \pm 16$ \\
\hline
\end{tabular}

Results of hemoglobin, $\mathrm{MCH}$, absolute numer of PMN and 17- $\beta$ estradiol in rats before PH 18 hour after PH. M resp. F - male resp. female sham manipulated, M-w resp. F-w - male resp. female blood withdrawal every week. The comparison of two values signalizes identical symbols. One sign represents $p<0.05$, two signs represents $p<0.01$, three signs represent $\mathrm{p}<0.001$.

Table 3. Iron concentration, total iron binding capacity in serum.

\begin{tabular}{|c|c|c|c|c|}
\hline & \multicolumn{2}{|c|}{ Serum iron concentration $(\mu \mathrm{mol} / 1)$} & \multicolumn{2}{|c|}{ Serum iron binding capacity } \\
\hline & $\begin{array}{c}\text { Before } \\
\text { PH }\end{array}$ & $\begin{array}{c}\text { After } \\
\mathrm{PH}\end{array}$ & $\begin{array}{c}\text { Before } \\
\text { PH }\end{array}$ & $\begin{array}{c}\text { After } \\
\mathrm{PH}\end{array}$ \\
\hline M & $\begin{array}{c}37 \pm 2 \\
* *\end{array}$ & $14 \pm 1$ & $\begin{array}{c}104 \pm 3 \\
* * *\end{array}$ & $73 \pm 2$ \\
\hline $\mathrm{F}$ & $\begin{array}{r}65 \pm 8 \\
* * \mathrm{X} \\
\end{array}$ & $18 \pm 1$ & $\begin{array}{c}93 \pm 2 \\
+\end{array}$ & $65 \pm 1$ \\
\hline M-w & $50 \pm 9$ & $24 \pm 6$ & $\begin{array}{l}78 \pm 2 \\
* * *\end{array}$ & $70 \pm 2$ \\
\hline F-w & $87 \pm 6 x$ & $23 \pm 4$ & $\begin{array}{c}102 \pm 2 \\
+\end{array}$ & $68 \pm 2$ \\
\hline
\end{tabular}

Results of iron concentration, total iron binding capacity in serum in rats before PH 18 hour after PH. M resp. F - male resp. female sham manipulated, M-w resp. F-w - male resp. female blood withdrawal every week. The comparison of two values signalizes identical symbols. One sign represents $p<0.05$, two signs represents $p<0.01$, three signs represent $\mathrm{p}<0.001$. 


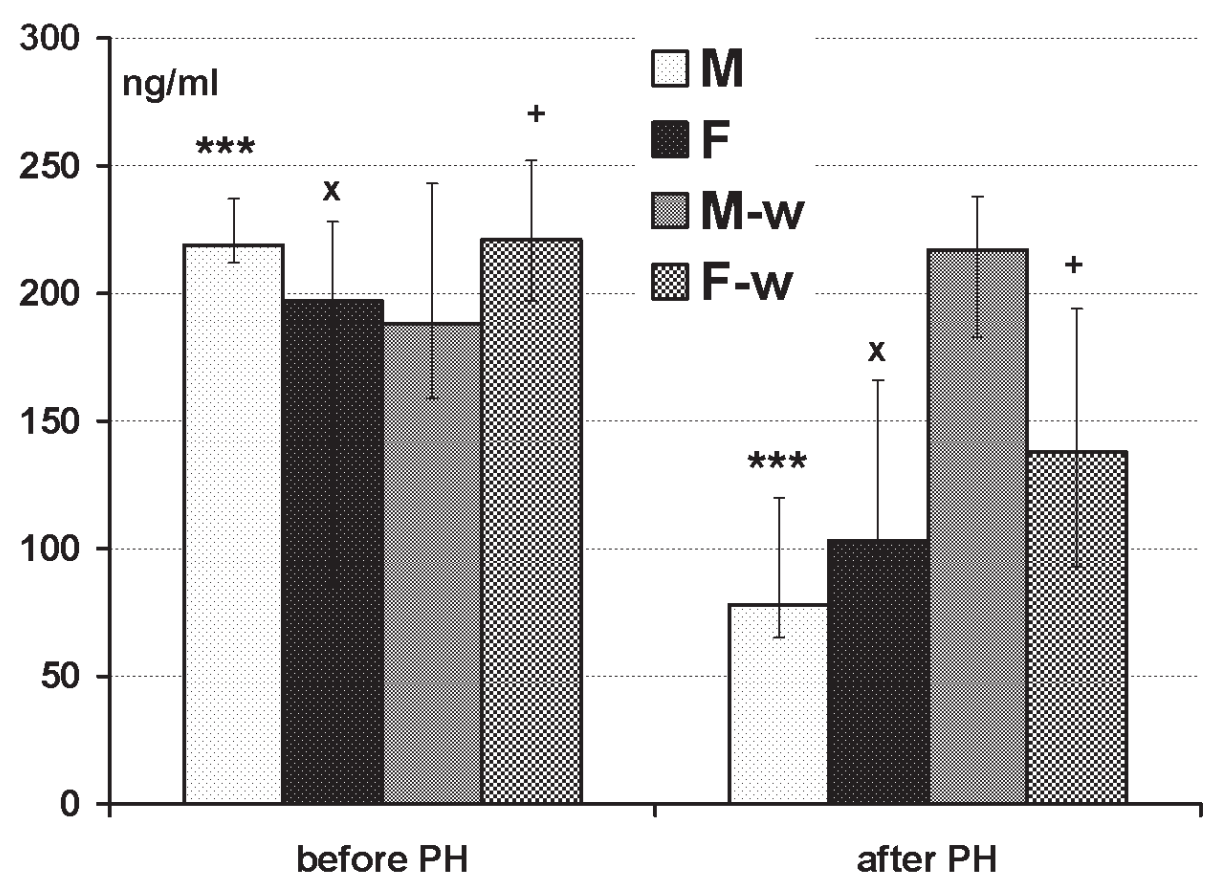

Fig. 1. Serum prohepcidin concentration ( $\mathrm{ng} / \mathrm{ml})$.

Results of serum prohepcidin concentration in rats before PH 18 hour after PH. M resp. F - male resp. female sham manipulated, M-w resp. F-w - male resp. female blood withdrawal every week. The comparison of two values signalizes identical symbols. One sign represents $p<0.05$, three signs represent $p<0.001$.

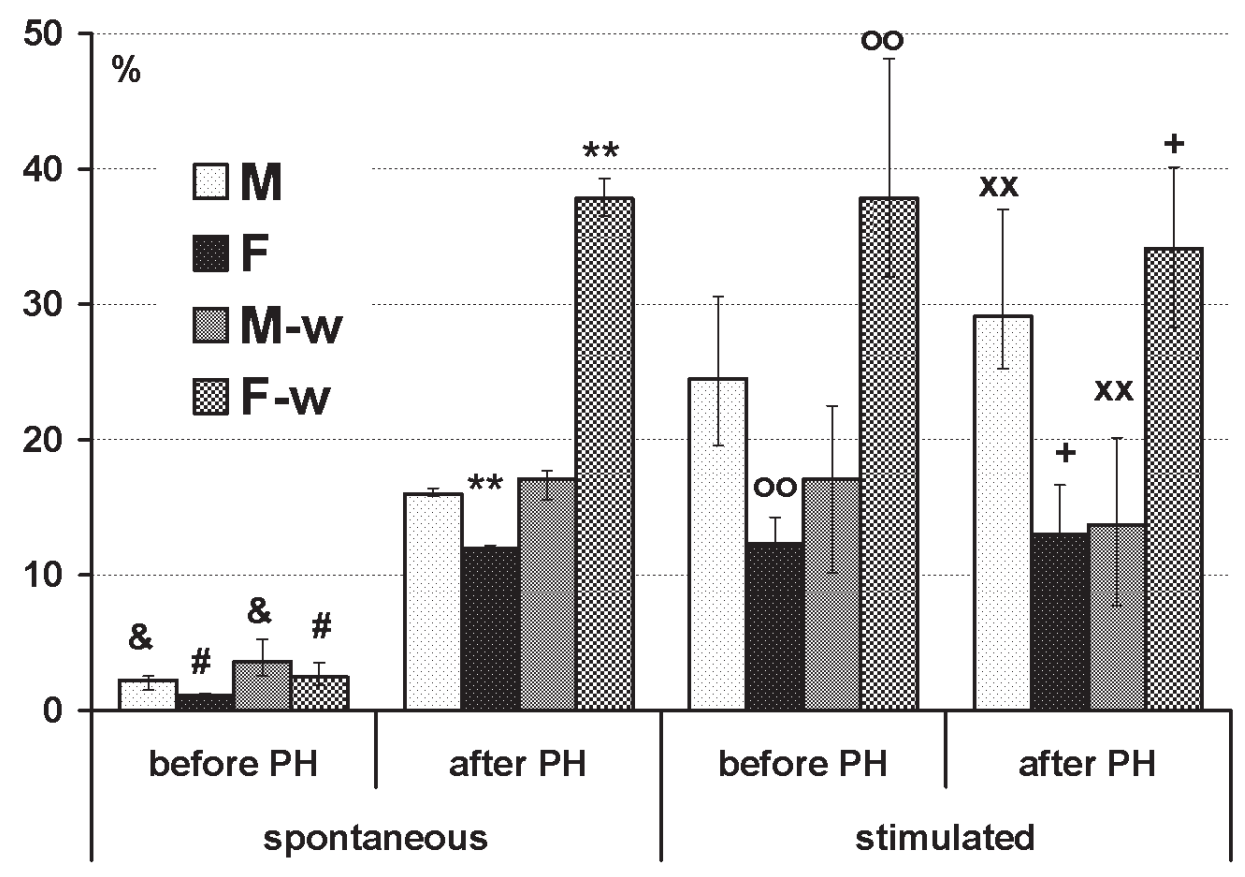

Fig. 2. Spontaneous and stimulated respiratory burst of blood PMN (\%).

Percentage of spontaneous and stimulated respiratory burst of blood PMN in rats before PH and 18 hour after PH. M resp. F - male resp. female sham manipulated, M-w resp. F-w - male resp. female blood withdrawal every week. The comparison of two values signalizes identical symbols. One sign represents $p<0.05$, two signs represent $\mathrm{p}<0.01$.

Serum prohepcidin concentration after $\mathrm{PH}$ decreased in $\mathrm{M}(\mathrm{p}=0.001), \mathrm{F}$, and $\mathrm{F}-\mathrm{w}(\mathrm{p}=0.05)$, on the contrary in group M-w not significantly increased.

There was notable statistical significant difference between genders in sham groups without blood withdrawals. The male rats had significantly more active PMN before and also after PH then females. The blood withdrawals themselves led to the increase of spontaneous respiratory burst of PMN in both sexes ( $<<0.05)$, but under influence of blood withdrawals was increased mainly in females F-w ( $p<0.01$ versus group F). The group M-w had lower values 
of stimulated burst of PMN before PH then group M. This trend was more significant after $\mathrm{PH}(\mathrm{p}<0.01)$.

The iron concentrations in serum were lower in all males then all females. The concentrations of iron was higher in both groups M-w and F-w in comparison with the groups $\mathrm{M}$ and $\mathrm{F}$. Decrease occurred in all groups after $\mathrm{PH}(\mathrm{p}<0.001)$, whereas this decrease regarding all parameters was the least significant in group M-w $(p<0.01)$. All groups noticed the decrease of the iron binding capacity $(\mathrm{p}<0.001)$ after $\mathrm{PH}$, less in group $\mathrm{M}-\mathrm{w}(\mathrm{p}<0.05)$.

\section{DISCUSSION}

The body weight of all rats was increasing during 10 weeks without statistical differences between $M$ vs. M-w and F vs. F-w. There were not any differences in diet feeding between the rats without and with blood withdrawals (data not presented).

Iron metabolism. Iron concentrations and protein saturations by iron were higher for both genders with repeated blood withdrawals in comparison with controls. The chronic iron deficiency induced by repeated blood withdrawals might be a cause of higher turnover of serum iron and its binding capacity. This iron turnover and transport is especially in female rats, which are physiologically capable to more absorb the iron during lactation and concurrently gestation period. This fact defends iron deficiency and anemia during pregnancy ${ }^{15}$. Iron content in liver representing the current iron store ${ }^{16}$, was significantly lower in group $\mathrm{M}$ then in group $\mathrm{F}$ and even then group F-w. We suppose that the females have their iron store easier mobilized for physiological requirements (gravidity, lactation, and - in our experiment for blood losses), which is demonstrated by higher turnover of the iron. The metabolism of iron in females is mostly influenced by estrogen, Horiguchi ${ }^{16}$ proved that estradiol elevated iron storage in the liver. The lower serum iron concentration and lower liver iron store with higher serum prohepcidin concentration were after $\mathrm{PH}$ in $\mathrm{M}-\mathrm{w}$ group only. The serum iron concentration and the iron binding capacity were decreased after PH less notably in M-w group then in other ones. This might be caused by remaining higher concentration of prohepcidin.

Liver regeneration. Both gender rats with repeated blood withdrawals had early beginning of liver regeneration after PH (higher liver DNA synthesis). There is an inconsistent influence of estrogen, because group $\mathrm{F}$ had the lowest liver DNA synthesis in comparison with F-w group, where is detected the highest liver DNA synthesis. It is possible that the higher DNA synthesis is evoked by higher estrogen levels. The positive effect of estrogen has been proved by other authors: Chiu et al. ${ }^{17}$ described that namely the estrogens promote liver regeneration after PH. Shimizu et al. ${ }^{18}$ demonstrated a positive influence of estradiol, among others endogenous antioxidant, on liver insult.

Preconditioning was evoked in organism by repeated blood withdrawals this effect was more expressed in the females then the males. The positive influence of pre- conditioning on $\mathrm{PH}$ has been proved by several authors: by abdominal laparotomy ${ }^{19}$, by periodic ischemia and liver reperfusion ${ }^{20}$, by hyperbaric oxygenation ${ }^{21}$. Repeated blood withdrawals stimulate metabolic iron turnover and partly evoked findings in vitro ${ }^{22}$. Chenoufi et al. ${ }^{22}$ have approved that the addition of iron lead to increase of ${ }^{3} \mathrm{H}$-methyl thymidine incorporation in primary culture of adult rat hepatocytes.

Blood count after PH. Group F-w before PH had higher hemoglobin concentration, even iron content in erythrocytes caused by erythropoesis stimulation. Even further the invariable hemoglobin concentration after PH was in $\mathrm{M}$-w and F-w groups. The leukopoesis stimulation has confirmed higher absolute numbers of PMN after PH in groups with blood withdrawals. The preconditioning may cause all these changes.

Serum prohepcidin concentration changes after $\mathrm{PH}$. The serum prohepcidin is synthesized by hepatocytes ${ }^{7}$ and in normal conditions its maturation is fully in the liver ${ }^{23}$. The prohepcidin changes occuring during liver injury are still not clear. The males with blood withdrawals and lower iron store had higher serum prohepcidin after $\mathrm{PH}$. On the contrary we found a decrease of serum prohepcidin concentration after $\mathrm{PH}$ in other groups; $\mathrm{M}(\mathrm{p}=0.001), \mathrm{F}$ and F-w $(p=0.05)$. We suppose that the higher prohepcidin concentration allowed absorption of iron from enterocyte, because prohepcidin was inefficient at degrading ferroportin ${ }^{24}$.

\section{Respiratory burst changes after $\mathrm{PH}$.}

The innate immunity is expressed by respiratory burst of PMN. Our experiment proved notable differences between genders in groups without blood withdrawals. Female PMN, suppressed by estradiol ${ }^{25}$, responsed in oxidative burst less then male PMN even before and also after $\mathrm{PH}$. According recent literature the estradiol reduced PMN superoxide production ${ }^{26}$ and the respiratory burst activity of $\mathrm{PMN}^{27}$. On the other hand testosterone accelerated lipid peroxidation in males ${ }^{28,29}$ as well as PMN activities in respiratory burst after single injury ${ }^{30}$.

Different situation occurred in the groups with repeated blood withdrawals. The group M-w had low activities of PMN before as well as after PH then the group M. This finding shows the exhaustion of innate immunity by chronic blood losses, by decrease of iron stores, by persisting high serum prohepcidin concentration; probably furin protease insufficiency ${ }^{24}$.

Repeated blood withdrawals activated PMN and macrophages in females and improved liver regeneration after $\mathrm{PH}$, together with higher estrogen and iron stores.

Study limitation. It is difficult to transform results to human medicine, because female rats do not lose periodically iron by menstruation. The physiological situation for female rats is numerous gravidities, when immediately after birth come next conception. The iron is accumulated to fetus (may be 8 times a year, about 10 newborns in weight from 7 to $8 \mathrm{~g}$ ) but also to placenta and to milk during 21 days of lactation. Female with body weight $350 \mathrm{~g}$ is able to be a mother to newborn weight $600 \mathrm{~g}$ per year. In this regard, you can see that the male rats with- 
out physiological loss of iron are in situation like regular blood donators.

\section{CONCLUSIONS}

The preconditioning (blood withdrawals) leads to increase of iron turnover and iron stores in organism following better reactivity of PMN in respiratory burst, faster decrease of serum prohepcidin, and early initiation of liver regeneration, mainly in females with their hormonal equipment.

\section{ACKNOWLEDGMENTS}

\section{Sponsored by Research project MZO 00179906.}

\section{REFERENCES}

1. Means RT Jr. Hepcidin and anaemia. Blood Rev 2004; 18:219-25.

2. Latunde-Dada GO, McKie AT, Simpson RJ. Animal models with enhanced erythropoiesis and iron absorption. Biochim Biophys Acta 2006; 1762:414-23.

3. Martin ME, Nicolas G, Hetet G, Vaulont S, Grandchamp B, Beaumont C. Transferrin receptor $1 \mathrm{mRNA}$ is downregulated in placenta of hepcidin transgenic embryos. FEBS Lett 2004 574:187-91.

4. Nemeth E, Rivera S, Gabayan V, Keller C, Taudorf S, Pedersen BK, et al. IL-6 mediates hypoferremia of inflammation by inducing the synthesis of the iron regulatory hormone hepcidin. J Clin Invest 2004; 113:1271-6.

5. Peyssonnaux C, Datta V, Cramer T, Doedens A, Theodorakis EA, Gallo RL, et al. HIF-1 $\alpha$ expression regulates the bactericidal capacity of phagocytes. J Clin Invest 2005; 115:1806-15.

6. Schranz M, Bakry R, Creus M, Bonn G, Vogel W, Zoller H Activation and inactivation of the iron hormone prohepcidin: Biochemical characterization of prohepcidin cleavage and sequential degradation to N-terminally truncated prohepcidin isoforms. Blood Cells Mol Dis 2009; 43:169-79.

7. Valore EV, Ganz T. Posttranslational processing of prohepcidin in human hepatocytes is mediated by the prohormone convertase furin. Blood Cells Mol Dis 2007; 40:132-138.

8. Goldman DL, Zeng W, Rivera J, Nakouzzi A, Casadevall A. Human serum contains a protease that protects against cytotoxic activity of Bacillus anthracis lethal toxin in vitro. Clin Vaccine Immunol 2008; 15:970-3.

9. Halliwell B, Gutteridge JMC. Role of free radicals and catalytic metal ions in human disease: an overview. Methods Enzymol 1990; 186:1-85.

10. Dahlgren C, Karlsson A. Respiratory burst in human neutrophils. J Immunol Methods 1999; 232:3-14.

11. Ayres S, Baer J, Subbiah MT. Exercise-induced increase in lipid peroxidation parameters in amenorrheic female athletes. Fertil Steril 1998; 69:73-7.

12. Short J, Zemel R, Kanta J, Lieberman I. Stimulation of deoxyribonucleic acid synthesis in the liver parenchymal cells of the intact rats. Nature 1969; 223: 956-7.
13. Burton K. A study of the condition and mechanism of the colorimetric estimation of deoxyribonucleic acid. Biochem J 1956; 62:315-323.

14. Wilhelm J, Frydrychova M, Hezinova A, Vizek M. Production of hydrogen peroxide by peritoneal macrophages from rats exposed to subacute and chronic hypoxia. Physiol Res 1997; 46:35-9.

15. Gambling L, Dunford S, Wallace DI, Zuur G, Solanky N, Srai SK, et al. Iron deficiency during pregnancy affects postnatal blood pressure in the rat. J Physiol 2003; 552:603-10.

16. Horiguchi H, Oguma E, Kayama F. The effects of iron deficiency on estradiol-induced suppression of erythropoietin induction in rats: implications of pregnancy-related anemia. Blood 2005; 106:67-74.

17. Chiu EJ, Lin HL, Chi CW, Liu TY, Lui WY. Estrogen therapy for hepatectomy patients with poor liver function? Med Hypotheses 2002; 58:516-8.

18. Shimizu I. Impact of oestrogens on the progression of liver disease. Liver Int 2003; 23:63-9.

19. Laurent S, Starkel P, Leclercq IA, Lambotte L, Maiter D, Horsmans Y. Molecular events associated with accelerated proliferative response in rat livers when partial hepatectomy is preceded by a sham operation. Eur J Clin Invest 2005; 35:140-7.

20. Bedirli A, Kerem M, Pasaoglu H, Erdem O, Ofluoglu E, Sakrak O. Effects of ischemic preconditioning on regenerative capacity of hepatocyte in the ischemically damaged rat livers. J Surg Res 2005; 125:42-48.

21. Kurir TT, Markotic A, Katalinic V, Bozanic D, Cikes V, Zemunik $\mathrm{T}$, et al. Effect of hyperbaric oxygenation on the regeneration of the liver after partial hepatectomy in rats. Braz J Med Biol Res 2004; 37:1231-7.

22. Chenoufi N, Loreal O, Drenou B, Cariou S, Hubert N, Leroyer P, et al. Iron may induce both DNA synthesis and repair in rat hepatocytes stimulated by EGF/pyruvate. J Hepatol 1997; 26:650-8.

23. Park $\mathrm{CH}$, Valore EV, Waring AJ, Ganz T. Hepcidin, a urinary antimicrobial peptide synthesized in the liver. J Biol Chem 2001; 276:7806-10

24. Gagliardo B, Kubat N, Faye A, Jaouen M, Durel B, Deschemin $\mathrm{JC}$, et al. Pro-hepcidin is unable to degrade the iron exporter ferroportin unless maturated by a furin-dependent process. Hepatol 2009; 50:394-401.

25. Bekesi G, Kakucs R, Varbiro S, Racz K, Sprintz D, Feher J, et al. In vitro effects of different steroid hormones on superoxide anion production of human neutrophil granulocytes. Steroids 2000; 65:889-894.

26. Abrahams VM, Collins JE, Wira CR, Fanger MW, Yeaman GR. Inhibition of human polymorphonuclear cell respiratory burst by 17-beta-estradiol and 2,3,7,8-tetrachlorodibenzo-p-dioxin. Am J Reprod Immunol 2003; 50:463-72.

27. Kuhn-Velten WN, Pippirs U. Novel connections between NADPHinduced lipid peroxidation and cytochrome $\mathrm{P} 450$ inactivation, and antioxidant and enzyme protective properties of estradiol in gonadal membranes. Free Radic Res 1997; 26:125-33.

28. Bureau I, Gueux E, Mazur A, Rock E, Roussel AM, Rayssiguier Y: Female rats are protected against oxidative stress during copper deficiency. J Am Coll Nutr 2003; 22:239-46.

29. Wachnik A, Biro G, Biro L, Korom M, Gergely A, Antal M. Effect of sex hormones on copper, zinc, iron nutritional status and hepatic lipid peroxidation in rats. Nahrung 1993; 37:28-34.

30. Deitch EA, Ananthakrishnan P, Cohen DB, Xu da Z, Feketeova E, Hauser CJ. Neutrophil activation is modulated by sex hormones after trauma-hemorrhagic shock and burn injuries. Am J Physiol Heart Circ Physiol 2006; 291:H1456-65. 